\title{
SZILÁRDFY ZOLTÁN
}

\section{A MEGVÁLTÓ VÉRREL ÉLTETŐ SZENTHÁROMSÁG EGY KÜLÖNLEGES KÉPTÍPUS KÖZÉP-EURÓPÁBAN}

\author{
Hofher József jezsuita szerzetes \\ 60. születésnapjára baráti köszöntéssel
}

A Szentháromság, mint az univerzum és az emberlét centruma és tengelye, különösen a Trinitas-kultuszban kapott aktualitást. A Szentháromságot tagadó iszlám agresszió idején még egy sajátos jelentéstartalommal bővült, a minduntalan pusztító pestisjárványok következtében. A háború, az éhínség és a döghalál - „Tria Davidis mala" - ellenszereként a Hármas Legfőbb Jóság: az Atya, a Fiú, a Szentlélek az eszmény és az orvosság erejével hatott az addig ismert négy világrész, Európa, Ázsia, Afrika és Amerika számára, melyeknek allegorikus megjelenítése a jezsuiták müvészetének kedvelt témája. A számtalan magyarországi Szentháromság-emlékmü gyakran az I. Lipót fogadalmából 1679-ban alapított, a bécsi Grabenen álló monumentum formai változata, amely ezek eszmei előképe volt. A hazaiak között feltétlenül megemlítendő a soproni és a pestisjárványok fogadalmát beváltó váci, kecskeméti, szekszárdi, pozsonyi, nagyszombati, komáromi, valamint a kvalitása miatt kiemelkedő három impozáns monumentális alkotás, köztük a sziléziai Dionysius Ignatius Stanetti művei: a selmecbányai, mely egyben szabadtéri oltár is, a körmöcbányai, valamint a korponai Szentháromság-oszlopok. Várostörténeti jelentőségű a budavári Szentháromság-szobor, Umgleich Fülöp és Hörger Antal kivitelezésében, oldalain a járvány és az építés riportszerü reliefjeivel, valamint Bebó Károly óbudai Szentháromság-emlékműve. ${ }^{1} \mathrm{~A}$ várban pasztoráló jezsuiták 1725-ben szervezték meg a Congregatio Ss. Trinitatist, amelynek kultikus célja mellett a magyar polgárok gyámolítása is feladata volt. Figyelemre méltó a Padányi Bíró Márton által emeltetett veszprémi Szentháromság-oszlop számos magyar szentjével, amint azt Angyali Társaságnak Szövetsége című társulati könyve dedikációjában egy kolozsvári jezsuita megjegyezte: „... Weszprémben a' Szent Háromságnak, és ő körülötte az ö szenteinek statuáit, képeit mind faragott kövekbül föl állíttatá...".2

A Szentháromság emlékeinek ebben a szakrális élménykörében született Loyolai Szent Ignácnak a jezsuita Andrea Pozzo által tervezett, 1699-ben elkészült síroltára, oromzatán Leonardo Reti és Lorenzo Ottone kompozíciójával, melyen a világ legnagyobbnak tartott lazúrköve a glóbusz, a három Isteni személy koszorújában. ${ }^{3}$
A Szentháromság ikonográfiájában különleges képtípusnak számít a prágai premontrei kanonokok strahovi apátsági könyvtárában őrzött, Dionysius Strauss rajza alapján készült metszet, amely a szerző első felfedezett, rézmetszetű szentképe $(19,4 \times 13,2 \mathrm{~cm})$ (1. kép). Strauss az Olmütz melletti Hradisch (Hradiško u Olomouce) monostorában a rend művészének számított, munkáit ötletes tematikája miatt becsülték. Egy 1695-ös adat szerint bemutatott egy képet Bernhard Wanzke perjel születésnapjára, amely a megfeszített Krisztust az Atyával és a Szentlélekkel ábrázolta, a megváltó Fiú oldalából ömlő vérrel bárányok táplálkoztak. Kétségtelen, hogy a grafikai lap, melynek jelzete „P. Dion. Straus

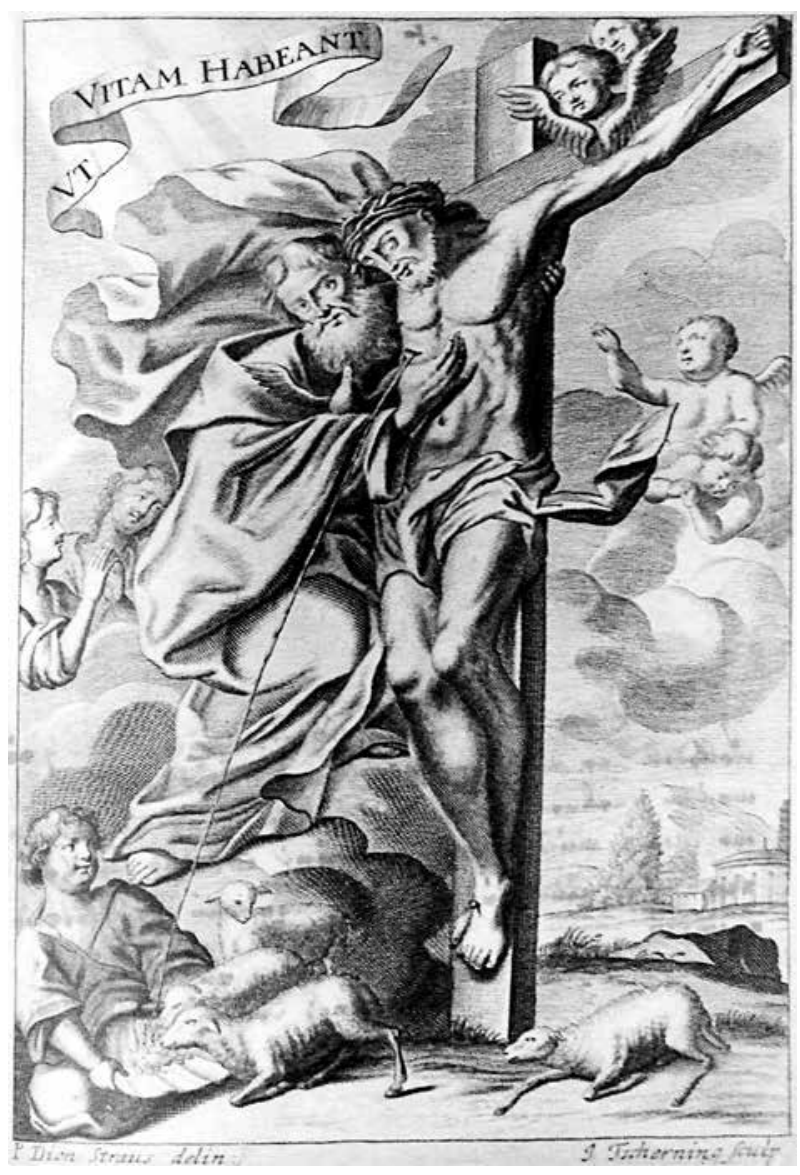

1. Dionysius Strauss - J. Tscherning: A Szentháromság. Rézmetszet, 1695 után. Praha-Strahov, Biblioteka Kanonia Premonstrátov (Reprodukció, Zelenková nyomán) 


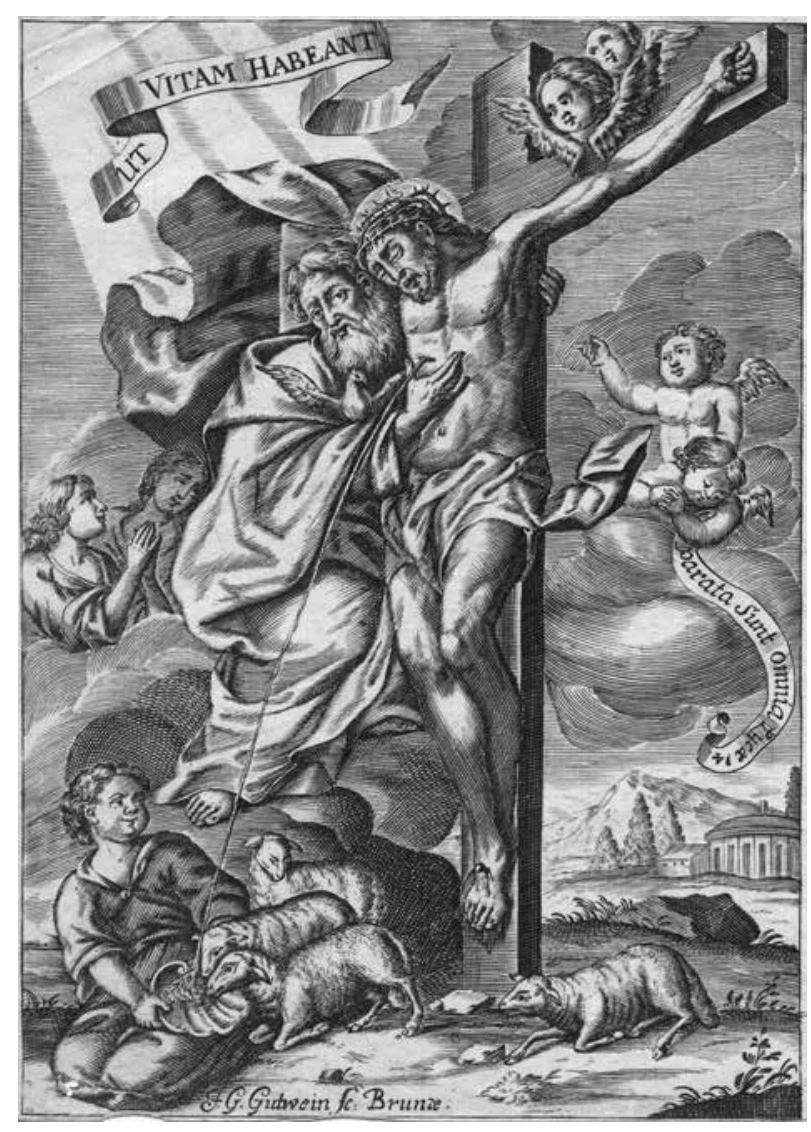

2. Johann Gaspar Gutwein: A Szentháromság. Rézmetszet, 1700 körül.

A szerző gyüjteményében

delin. - J. Tscherning sculp." a ma már elveszett festményről készült. A kompozíció fölötti szalagirat, „UT VITAM HABEANT”, azaz "hogy életük legyen" (Jn 10,10) Szent János Evangéliumából való. ${ }^{4}$

Szintén a 17. század végéről származik az előbbi téma kissé módosított változata, a Prágában, Brünnben, Augsburgban, Regensburgban és Grazban is müködő Johann Gaspar Gutwein (1669-1730) rézmetszete, amely címlapelőzék lehetett $(20,5 \times 16,5$ $\mathrm{cm})$, jelzete "J. G. Gutwein sc. Brunae" ${ }^{5}$ (2. kép). Magángyüjteményem ezen becses példányán a fentebb idézett evangéliumi szavakhoz kapcsolódva, a feszület mögött egy összekulcsolt kezü gyermek angyal könyökénél aláhulló írásszalagon olvasható másik idézet Szent Lukács Evangéliumából - „„... parata sunt omnia” (Lk 14, 17), „minden el van készítve" - utal az Üdvözítő nyájának lakomájára.

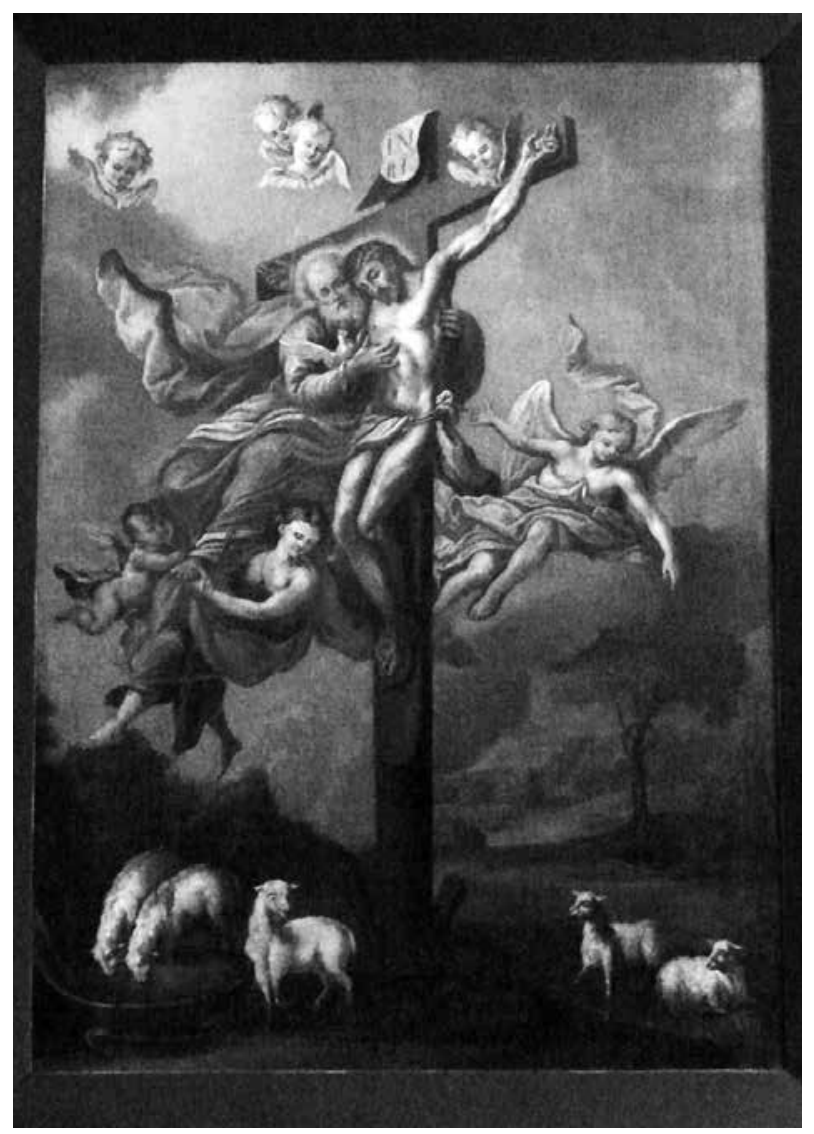

3. Közép-európai festő: A Szentháromság, 18. század. Bakonybél, Szent Mauriciusz bencés apátság

(Semsey Balázs felvétele)

A Krisztus oldalából fakadó, gyöngyház kagylóba gyüjtött vér és víz a keresztség és az eucharisztia életadó és fenntartó szentségeire mutat, amelytől a vézna bárányok erőre kapnak.

Alig ismert 18. századi olajfestményt őriz a bakonybéli Szent Mauríciusz bencés monostor ${ }^{6}$ (3. kép). Ezen a feliratok már nem szerepelnek; fehér bárányok táplálkoznak a Krisztus oldalából folyó, tálba gyüjtött éltető vérrel, mely egyben megtisztította őket. Ezért áll a háttérben a paradicsomi fa a rátekeredett kígyóval, melynek jóvátétele Krisztus keresztáldozata, aki a bün fáján győztes sátánt a keresztfán győzte le. A Szentháromság-ábrázolás e különleges változata a fentebb értelmezett müvek tanúsága szerint Közép-Európában a Tridentinum lelkiségi megújulását tükröző, katolikus Morvaországban született. 


\section{JEGYZETEK}

1 L. Aggházy Mária: A barokk szobrászat Magyarországon. Budapest 1959, I. 64-73, 107-109, legújabban: Barbara Balážová: StÍp Najsvätšej Trojice v Kremníci (1766-1772). Jeden z posledných morových stÍpov v bývalých habsburgských krajinách. Ars 35. 2002, č. 1-3. 135-184, irodalommal.

2 Szilárdfy Zoltán: A barokk évszázadok ikonográfiájának sajátos Szentháromság-típusai különös tekintettel a hazai emlékekre. In: Barna Gábor (szerk.): „Oh, boldogságos Háromság." Tanulmányok a Szentháromság tiszteletéről. Paulus Hungarus - Kairosz Kiadó, Budapest 2003, 38-39, 41-42.

3 Alberta Battisti (a cura di): Andrea Pozzo. Luni Editrice, Milano-Trento 2006, 19, 204-205. Pericoli
Ridolfini, Cecilia (a cura di): Roma chiesa del Gesù. Bologna, 1975. 25.

4 Petra Zelenková: Barokní grafika 17. století v zemích Koruny české / Seventeenth-Century Baroque Prints in the Lands of the Bohemian Crown. Praha 2009, 146-147. Mind az adatokat, mind pedig a közölt képek fotóit Terdik Szilveszter tudományos kutató, művészettörténésznek köszönöm.

$5 \mathrm{Az}$ eddig publikálatlan rézmetszet Serfőző Szabolcs tudományos kutató, művészettörténész ajándékaként került hozzám.

6 A képet közöltem: Szilárdfy i. m. 2003, 16. kép. Az őrzési hely megjelölését Terdik Szilveszternek köszönöm.

\section{THE HOLY TRINITY WITH THE SAVIOUR'S BLOOD AS NUTRIMENT A PECULIAR PICTURE TYPE IN CENTRAL EUROPE}

A special iconographic interpretation of the Holy Trinity is represented by an engraving kept in the Strahov abbey library of the Premonstratensian canons of Prague. The print was made after Dionysius Strauss' drawing and is the artist's first extant holy image engraved in copperplate. In the monastery of Hradiško u Olomouce Strauss was regarded as the artist of the order respected for the inventiveness of his themes. It is a known fact from 1695 that he presented a painting on the birthday of prior Bernard Wanzke showing the crucified Christ with the Father and the Holy Spirit with lambs feeding on the blood gushing forth from the Son's side. Undoubtedly, the graphic sheet marked "P. Dion. Straus delin. - J. Tscherning sculp." was made after the lost painting. The words in the banderole above the composition "ut vitam habeant" (that they may have life) are from St John's gospel (Jn 10,10).

A somewhat modified variant of the theme is a copperplate engraving also from the late 17th century by Johann Gaspar Gutwein (1669-1730) who worked in Prague, Brno, Augsburg, Regensburg and Graz. The print marked "J. G. Gutwein sc. Brunae" probably adorned the flyleaf of a book. This precious specimen of my private collection shows an infant angel with clasped hands behind the cross, with a quotation from St Luke's gospel on the banderole falling down by its elbow: "... parata sunt omnia" (all things are now ready, Luke 14,17). The words refer to the feast of the flock of the Saviour. The blood and water from the side of Christ collected in a pearl-shell refer to the life-giving and maintaining sacraments of baptism and the eucharist from which the scrawny lambs will gain strength.

There is a little known 18th century oil painting in the St Maurice Benedictine monastery of Bakonybél. There are no inscriptions, but white lambs are feeding on the life-giving blood which has cleaned them, flowing from Christ's side into a bowl. The tree of paradise with the serpent is in the background to indicate that Christ's sacrifice on the cross was made in reparation of the original sin: Christ defeated Satan on the cross. This peculiar version of the Holy Trinity representations originated from catholic Moravia in the Tridentine revival of spirituality in Central Europe, as the above described depictions suggest.

SZILÁRDFY Zoltán művészettörténész / art historian, H-1073 Budapest, Barcsay u. 16.

Kulcsszavak: Szentháromság, 17. század, rézmetszetek, Morvaország, vér, bárány / Keywords: Holy Trinity, 17th century, copperplate engravings, Moravia, blood, lamb 
